\title{
PENERAPAN SENAM REMATIK TERHADAP PENURUNAN SKALA NYERI PADA ASUHAN KEPERAWATAN RHEUMATOID ARTHRITIS DI KELURAHAN GEBANGREJO
}

\author{
The Implementation of Rheumatic Gymnastics to Decrease Pain Scale \\ in Rheumatoid Arthritical Nursing Care in Gebangrejo \\ Agusrianto, Dewi Nurviana Suharto*, Nirva Rantesigi, Tasnim \\ Poltekkes Kemenkes Palu \\ *Email korespondensi: dewinurviana.suharto@gmail.com,
}

\begin{abstract}
ABSTRAK
Pendahuluan: Rheumatoid arthritis merupakan kelainan autoimun yang menyebabkan inflamasi sendi yang berlangsung kronik dan mengenai lebih dari lima sendi (poliartritis). Gejala yang sering muncul ialah kekakuan di pagi hari. Pengobatan secara nonfarmakologi dapat dilakukan dengan mengubah gaya hidup yang lebih sehat dan melakukan terapi fisik (senam rematik) yang bisa dilakukan setiap hari. Tujuan: Menggambarkan penerapan Teknik Senam Rematik Terhadap Nyeri Sendi Pada Asuhan Keperawatan Gerontik Dengan Rheumatoid arthritis. Metode Penelitian: yaitu dengan menggunakan metode pendekatan observasional deskriptif dengan desain penelitian studi kasus. Hasil Penelitian: Setelah dilakukan penerapan senam rematik selama 7 hari pada Ny. S didapatkan hasil nyeri pada kaki berkurang. Penerapan senam rematik dapat menurunkan skala nyeri yang dirasakan Ny. S dari (skala 8 (0-10) menjadi 6 (0-10). Saran: Diharapkan klien mampu melakukan terapi fisik (senam rematik) ketika pasien mengalami atau merakan nyeri pada bagian ektremitas.
\end{abstract}

Kata kunci: rheumatoid arthritis, nyeri sendi, senam rematik;

\begin{abstract}
Introduction: Rheumatoid arthritis is an autoimmune disorder that causes chronic inflammation of the joints and affects more than five joints (polyarthritis). The most common symptom is morning stiffness. Non-pharmacological treatment can be done by changing a healthier lifestyle and doing physical therapy (rheumatic exercise) which can be done every day. A useful aim: to general objectives describe the application of rheumatic gymnastics techniques to joint pain in gerontic nursing care with rheumatoid arthritis. Search Methods: . The research method is to use a descriptive observational approach with a case study research design. Results: After implementing rheumatic exercises for 7 days at Mrs. S results in reduced leg pain. The application of rheumatic exercises can reduce the pain scale felt by Mrs. S from (scale 8 (0-10) to 6 (0-10). Suggestion: It is expected that the client will be able to perform physical therapy (rheumatic exercise) when the patient experiences or experiences pain in the extremities.
\end{abstract}

Keywords : rheumatoid arthritis, joint pain, rheumatic exercises;

https://doi.org/10.33860/mnj.v1i1.265

(C) 2020 by the authors. Submitted for possible open access publication under the terms and conditions of the Creative Commons Attribution (CC BY SA) license (https://creativecommons.org/licenses/by-sa/4.0/).

\section{PENDAHULUAN}

Lansia adalah seseorang yang telah memasuki usia 60 tahun ke atas. Lansia merupakan kelompok umur pada manusia yang telah memasuki tahapan akhir dari fase kehidupannya. Pada tahun 2014, jumlah penduduk lanjut usia di Indonesia berkisar 18.781 jiwa dan angka harapan hidup di Indonesia meningkat dari 68,6 tahun di tahun 2004 menjadi 70,8 tahun di tahun 2015. Pada tahun 2035 diperkirakan meningkat lagi menjadi 72,2 tahun. ${ }^{1}$

Seiring dengan peningkatan persentase lansia terjadi juga peningkatan jumlah dan tingkat kejadian penyakit kronis yang disebabkan oleh penurunan kemampuan tubuh untuk beradaptasi dengan stres lingkungan serta kelemahan pada lansia. Tujuh golongan penyakit yang banyak dilaporkan terjadi pada lansia adalah arthritis, hipertensi, gangguan 
pendengaran, kelainan jantung, sinusitis kronik, penurunan visus, dan gangguan pada tulang ${ }^{2}$. Masalah muskuloskeletal seperti arthritis dan gangguan pada tulang menjadi masalah yang sering terjadi pada lansia karena mempengaruhi aktivitas yang merupakan hal vital bagi kesehatan total lansia. Arthritis merupak penyebab utama munculnya nyeri sendi. Nyeri sendi merupakan nyeri yang dirasakan dibagian persendian dan sekitarnya akibat proses inflamasi maupun terjadi secara idiopatik. ${ }^{2}$

Angka kejadian Rhematoid Arthritis pada tahun 2018 yang dilaporkan oleh organisasi kesehatan dunia WHO mencapai $20 \%$ dari penduduk dunia, dimana $20 \%$ tersebut adalah mereka yang berusia 55 tahun ke atas, sedangkan laporan Hasil Riset Kesehatan Dasar (Riskesdas) Indonesia tahun 2018 prevalensi penyakit Rhematoid Arthritis adalah 24,7\% ${ }^{3}$. Data di Kabupaten Poso pada tahun 2019 jumlah keseluruhan penderita Rheumatoid Arthritis sebanyak 2.112 pasien. $^{4}$

Rheumatoid arthritis ini merupakan kelainan autoimun yang menyebabkan inflamasi sendi yang berlangsung kronik dan mengenai lebih dari lima sendi (poliartritis). Gejala yang yang sering muncul ialah kekakuan di pagi hari selama lebih dari satu jam, dapat bersifat generalisata tetapi terutama menyerang sendi - sendi. Kekakuan ini berbeda dengan kekakuan sendi pada osteoartritis, yang biasanya hanya berlangsung selama beberapa menit dan selalu berulang dari satu jam. Belum ada pengobatan yang dapat digunakan untuk menyembuhkan rheumatoid arthritis. ${ }^{2}$

Salah satu dari olahraga fisik yang sederhana dan mudah dilakukan adalah senam rematik ${ }^{5}$. Senam rematik merupakan senam yang befokus pada mempertahankan lingkup gerak sendi secara maksimal. Tujuan dari senam rematik ini yaitu mengurangi nyeri sendi dan menjaga kesehatan jasmani penderita rematik. Keuntungan lain dari senam rematik yaitu tulang menjadi lebih lentur, otot tetap kencang, memperlancar peredaran darah, menjaga kadar lemak darah tetap normal, tidak mudah mengalami cidera, dan kecepatan reaksi sel tubuh menjadi lebih baik. ${ }^{6}$

Penelitian Pujiati \& Mayasari (2017) tentang Pengaruh senam rematik terhadap nyeri sendi pada lansia di Panti Sosial Tresna Werdha Budimulia 04 Margaguna Jakarta Selatan melaporkan bahwa manfaat dari senam rematik yaitu dapat mengurangi nyeri sendi dan menjaga kesehatan jasmani penderita rematik, tulang menjadi lebih lentur, otot tetap kencang, memperlancar peredaran darah, menjaga kadar lemak darah tetap normal, tidak mudah mengalami cidera, dan kecepatan reaksi sel tubuh menjadi lebih baik. Setelah diajarkan senam rematik pada Ny. P nyeri berkurang pada daerah kakit kiri dan bahu kanan, yang sebelumnya dengan skala nyeri 7 $\mathrm{Ny}$. P mengeluh terganggu tidak bisa melakukan aktivitas sehari-hari secara mandiri dan masih tergantung pada keluarga. Setelah dilakukan senam rematik selama 2 minggu nyerinya berkurang dengan skala nyeri menjadi 3. Senam rematik yang dilakukan 2-3 kali dalam seminggu dengan durasi waktu selama 30-60 menit, badan terasa rileks, dan segar. ${ }^{7}$

Berdasarkan fenomena tersebut, maka penulis melakukan penelitian mengenai Penerapan Senam Rematik Terhadap Penurunan Skala Nyeri Pada Asuhan Keperawatan Gerontik dengan Kasus Rheumatoid Arthritis Di Kelurahan Gebangrejo.

\section{METODE PENULISAN}

Penulisan ini menggunakan metode studi kasus, yaitu analisis penerapan relaksasi otot progresif pada asuhan keperawatan diabetes melitus dengan masalah keperawatan ansietas. Adapun teknik pengumpulan data yang digunakan meliputi wawancara, observasi, catatan individu, atau rekam medik dan perawatan. Data yang telah terkumpul dianalisis untuk melihat masalah keperawatan yang dialami klien serta meninjau keefektifan intervensi yang telah dilakukan untuk menyelesaikan masalah keperawatan pasien.

\section{HASIL PENELITIAN}

Hasil pengkajian didapatkan data : Klien Ny. P, umur 64 tahun, jenis kelamin perempuan, pendidikan terakhir SD, agama islam, status pernikahan menikah, tinggi badan $150 \mathrm{~cm}$ berat badan $54 \mathrm{~kg}$, penampilan rapi, warna kulit sawo matang, dan beralamat di jalan Pulau Tarakan Kelurahan Gabangrejo Timur. Klien Ny. P mengatakan nyeri, nyeri pada bagian kaki, nyeri bertambah saat beraktifitas, skala nyeri 4 , dan nyeri dirasakan sampai sehari yaitu ketika dirasakan pada pagi hari sampai sebelum meminum obat untuk menghilangkan nyeri.

Pemeriksaan fisik Ny.P, Keadaan Umum baik, kesadaran composmentis. Tekanan darah 130/100 $\mathrm{mmHg}$, Nadi 96X/menit, respirasi 22X/menit, suhu $36,5^{\circ} \mathrm{C}$. Bentuk kepala branchiocepalus, tidak terdapat nyeri tekan, pandangan kabur, pendengaran berkurang, tidak ada pembesaran kelenjar tyroid, dada 
simetris kiri dan kanan, tidak terlihat penggunaan otot bantu pernapasan, bentuk dada normal chest, tidak terdapat nyeri tekan, bentuk perut datar, tidak terdapat lesi, tidak ada benjolan, bising usus $12 \mathrm{x} /$ menit, perkusi terdengar timpani, dan tidak terdapat nyeri tekan, klien mampu merubah posisi, fleksi dan ekstensi kedua lengan tidak ada hambatan, flekasi dan ekstensi sendi kaki terhambat karena nyeri dan bengkak pada sendi, terasa nyeri dan kaku pada pagi hari, nyeri dirasakan seperti ditusuk-tusuk, skala nyeri 4, durasi nyeri lebih dari 20 menit.

Penilaian aktivitas klien Ny. $\mathrm{P}$ berdasarkan Indeks KATZ Ny. P memiliki skor nilai A yang artinya kemandirian dalam hal makan, berpindah, ke kamar kecil, berpakaian, dan mandi. Artinya adalah kegiatan atau aktivitas yang Ny. P lakukan sehari-hari masih dapat di kerjakan secara mandiri.

Berdasarkan hasil pengkajian yang dilakukan penulis, didapatkan masalah keperawatan pada pasien Ny. P yaitu nyeri kronis, dan Hambatan mobilitas fisik. Berdasarkan diagnosa keperawatan yang didapatkan pada Ny. P penulis berfokus pada salah satu diagnosa keperawatan prioritas yaitu nyeri kronis ditandai dengan data subjektif $\mathrm{Ny}$. P mengatakan nyeri pada bagian kaki, susah tidur saat nyeri datang pada malam hari, sering terbangun dimalam hari, KU: sedang, kesadaran: composmentis, skala nnyeri 8 (0-10), klien terlihat kesulitan berpindah tempat, klien terlihat meringis.

\section{PEMBAHASAN}

Asuhan keperawatan memfokuskan pada pemenuhan kebutuhan dasar manusia melalui tahap pengkajian, diagnosa keperawatan, intervensi keperawatan, implementasi dan evaluasi. Rheumatoid arthritis adalah suatu penyakit inflamasi kronis yang menyebabkan degenerasi jaringan penyambung. Jaringan penyambung yang biasanya mengalami kerusakan adalah membran sinovial yang melapisi persendian. Inflamasi akan menyebar ke struktur sekitar sendi, termasuk kartilago artikular dan kapsula sendi fibrosa. Gejala yang yang sering muncul ialah kekakuan di pagi hari selama lebih dari satu jam, dapat bersifat generalisata tetapi terutama menyerang sendi-sendi. Salah satu cara mengontrol nyeri sendi yaitu dengan latihan terapi fisik (senam rematik). Senam rematik merupakan senam yang befokus pada mempertahankan lingkup gerak sendi secara maksimal. Tujuan dari senam rematik ini yaitu mengurangi nyeri sendi dan menjaga kesehatan jasmani penderita rematik. $^{7}$

Pada saat pengkajian klien Ny. P merasakan nyeri lebih dari 1 jam (skala nyeri 8), susah tidur pada malam hari serta Ny. P merasa gelisah. Nyeri pada ekstremitas bawah yang dirasakan klien bertambah saat klien beraktivitas (skala nyeri bisa sampai 9). Klien Ny. P mengalami penyakit Rheumatoid arthritis sejak tahun 2017. Intervensi yang dilakukan pada klien Ny. P untuk menurunkan skala nyeri yaitu cara nonfarmakologi dengan menggunakan senam rematik. Setelah diberikan intervensi selama 1 minggu, keluhan nyeri dipagi hari berkurang, klien menjadi lebih rileks. Intervensi yang dilakukan yaitu : manajemen nyeri. Tindakan keperawatan yang di lakukan untuk mengatasi masalah keperawatan nyeri kronis berhubungan dengan inflamasi sendi, adalah terapi fisik (senam rematik).

Setelah dilakukan implementasi selama 7 hari dan melakukan evaluasi keperawatan akhir, masalah nyeri kronis menurun, diperoleh data subyektif pasien mengatakan pasien mulai menerima status kesehatannya. Sedangkan data obyektif yang diperoleh, klien tampak tidak gelisah lagi. Analisa masalah nyeri teratasi. planing pertahankan intervensi.

Dari hasil penelitian yang dilakukan pada klien Ny. $P$ sebelum dilakukan senam rematik, Ny. $P$ mengatakan bahwa ia merasakan nyeri semakin bertambah, susah tidur serta merasa gelisah. Nyeri yang dirasakan seperti ditusuk-tusuk benda tajam, durasi nyeri selama lebih dari 1 jam. Untuk itu peneliti menerapkan teknik non-farmakologi yaitu terapi fisik (senam rematik). Pemberian senam memiliki dampak psikologis langsung yakni membantu memberi perasaan santai, mengurangi ketegangan dan meningkatkan perasaan senang karena saat senam kelenjar pituitari menambah produksi beta-endorfin. Senam juga memperlancar kegiatan penyalur syaraf didalam otak yaitu meningkatkan neurotransmitter parasimpatis (norepinephrine, dopamine dan serotonin). Meningkatnya konsentrasi beta-endorfin didalam darah dan parasimpatis ini menyebabkan denyut jantung dan denyut nadi menurun sehingga mengurangi nyeri yang merupakan penyebab kekakuan sendi. ${ }^{5}$

Hasil penelitian pada klien Ny. P setelah dilakukan pemberian senam rematik selama 1 minggu berturut-turut menunjukan perubahan yang signifikan, sebelum dilakukan terapi skala nyeri $\mathrm{Ny}$. P 
yaitu 8 , tetapi setelah dilakukan terapi selama 1 minggu tekanan darah Ny. P turun menjadi 5, dan Ny. $\mathrm{P}$ mengatakan setelah dilakukan terapi fisik ini Ny. $\mathrm{P}$ lebih tampak rileks, Ny. P juga mengatakan nyeri pada bagian ektremitas bawah berkurang, Ny. P tampak lebih nyaman dan tenang setelah dilakukan terapi senam rematik, pada kondisi Ny. $\mathrm{P}$ yang lebih rileks, yang terjadi adalah penurunan skala nyeri dengan menggunakan terapi non-farmakologi yaitu dengan senam rematik ini.

Hal ini didukung dalam penelitian yang dilakukan oleh Sitinjak et al (2016) bahwa manfaat dari senam rematik yaitu dapat mengurangi nyeri sendi dan menjaga kesehatan jasmani penderita rematik, tulang menjadi lebih lentur, otot tetap kencang, memperlancar peredaran darah, menjaga kadar lemak darah tetap normal, tidak mudah mengalami cidera, dan kecepatan reaksi sel tubuh menjadi lebih baik. ${ }^{6}$ Setelah dilakukan senam rematik selama 2 minggu nyerinya berkurang dengan skala nyeri menjadi 3 . Senam rematik yang dilakukan 2-3 kali dalam seminggu dengan durasi waktu selama 3060 menit, badan terasa rileks, dan segar

\section{SIMPULAN DAN SARAN}

Kesimpulan senam rematik dapat menurunkan skala nyeri pada penderita rheumatoid arthritis, penerapan teori yang dilakukan peneliti tidak mempunyai kesenjangan dengan penelitian sebelumnya bahwa pemberian senam rematik pada pagi hari selama 7 hari berturut-turut dalam waktu 20 menit efektif untuk menurunkan skala nyeri sendi pada Ny. P serta membuat lebih rileks. Diharapkan dapat memahami informasi tentang terapi untuk menurunkan skala nyeri dengan cara non- farmakologi.

\section{DAFTAR PUSTAKA}

1. Fatmah. Gizi Usia Lanjut. Jakarta: Erlangga; 2016.

2. Stanley M. Buku ajar keperawatan gerontik (Gerontological nursing: A health promotion or protection approach). Jakarta: EGC; 2015.

3. Kementrian Kesehatan Republik Indonesia. Laporan Hasil Riset Kesehatan Dasar [Internet]. 2018. Available from: https://www.litbang.kemkes.go.id/laporan-risetkesehatan-dasar-riskesdas/

4. Dinas Kesehatan Kabupaten Poso. Jumlah Penderita Rheumathoid Arthritis di Kabupaten Poso. 2018.

5. Nurhidayah K. Pengaruh senam rematik terhadap aktifitas fungsional lansia di komunitas senam lansia Wilayah Kelurahan Nusukan Banjarsari Surakarta. Universitas Muhammadiyah Surakarta; 2012.

6. Sitinjak V, Hastuti MF, Nurfiant A. Pengaruh Senam Rematik terhadap Perubahan Skala nyeri. Universitas Tanjungpura Pontianak; 2016.

7. Pujiati E, Mayasari A. Senam Rematik Terhadap Peningkatan Kualitas Hidup Lansia Ny.S Keluarga Tn.A Dalam Melakukan Adl (Activity Daily Living) Dukuh Pendem Kulon Desa Jepang Kecamatan Mejobo Kabupaten Kudus. J Profesi Keperawatan. 2017;3:7-16.

8. Tarwoto, Wartonah. Kebutuhan Dasar Manusia dan Proses Keperawatan. 4th ed. Jakarta: Trans Info Medika; 2015.

9. Stuart G. Principles and Practice of Psychiatric Nursing. 7th ed. Philadephia: Mosby; 2013. 